\title{
Implementasi Bimbingan Belajar Mengulang Kelas dalam Menumbuhkan Kemampuan Akademik Siswa Baru di Madrasah Qudsiyyah Kudus
}

\author{
Moh. Anwar Yasfin \\ IAIN Kudus, Jawa Tengah, Indonesia \\ myasfin@iainkudus.ac.id
}

Ahmad Nilnal Munachifdlil 'Ula

Universitas Muria Kudus, Jawa Tengah, Indonesia

ahmad.nilnalmuna@umk.ac.id

\begin{abstract}
Abstrak
Penelitian ini bertujuan untuk mendeskripsikan implementasi bimbingan belajar mengulang kelas dalam menumbuhkan kemampuan akademik siswa baru di Madrasah Qudsiyyah Kudus Penelitian ini mengunakan Metode Riset Lapangan (field research) dengan teknik analisis deskriptif kualitatif. Data penelitian yang terkumpul kemudian dianalisis dengan menggunakan pendekatan deduktif dan pendekatan induktif. Hasil penelitian menunjukkan bahwa pertama, proses bimbingan dalam mengulang kelas bagi siswa baru yang masuk di madrasah Madrasah Qudsiyyah Kudus adalah Saat mau masuk ke jenjang Madrasah Tsanawiyah, mereka harus mengulang kelas dahulu di kelas MI secara sukarela, kendati mereka telah lulus SD atau MI. Kedua, Bimbingan belajar mengulang kelas yang dilaksanakan di Madrasah Qudsiyyah adalah dengan mengelompokkan sesuai kemampuannya. Ketiga, Model bimbingan belajar mengulang kelas di Madrasah Qudsiyyah dilakukan secara kelompok dengan membentuk kurikulum tersendiri yang mana dapat fokus pada kurikulum salafiyah dsar sebagai bekal materi salafiyah di tingkat lanjutan. Keempat, Pembimbing materi salafiyah dasar ini dilakukan oleh semua guru, tidak hanya dibebankan pada guru BK.
\end{abstract}

Kata kunci: Bimbingan, Mengulang kelas, Madrasah Qudsiyyah 


\begin{abstract}
Implementation of Class Repetition Guidance in Developing Academic Ability of New Students at Madrasah Qudsiyyah Kudus. This study aims to describe the implementation of repeating class tutoring in growing the academic abilities of new students at Madrasah Qudsiyyah Kudus. This study uses Field Research Methods (field research) with qualitative descriptive analysis techniques. The research data collected was then analyzed using a deductive approach and an inductive approach. The results showed that first, the guidance process in repeating classes for new students entering the Madrasah Qudsiyyah Kudus was that when they wanted to enter the Madrasah Tsanawiyah level, they had to repeat the first class in MI class voluntarily, even though they had graduated from SD or MI. Second, the tutoring for repeating the classes carried out at Madrasah Qudsiyyah is by grouping according to their abilities. Fourth, the tutoring model for repeating classes at Madrasah Qudsiyyah is carried out in groups by forming a separate curriculum which can focus on the basic salafiyah curriculum as a provision of salafiyah material at an advanced level. Fifth, this basic salafiyah guidance material is carried out by all teachers, not only burdened by counselors.
\end{abstract}

Keywords: Guidance, Repeating Class, Madrasah Qudsiyyah

\title{
A. Pendahuluan
}

Pendidikan tak lain merupakan tumpuan dan harapan untuk pengembangan individu dan generasi bangsa. Dari pendidikan inilah harapan masa depan dibangun dalam landasan yang kuat. Landasan yang berpijak pada normanorma moral agama. Landasan yang mampu memandirikan anak bangsa dengan berbagai potensi yang dimilikinya (Sulhan, 2010: 53). Pendidikan, dalam arti yang luas adalah proses pembudayaan anak untuk dibentuk sesuai potensi belajar yang dimilikinya dengan tujuan agar menjadi anggota penuh dari masyarakat yang dapat menghayati dan mengamalkan potensinya, baik secara individu maupun bersama-sama dengan anggota lainnya. Dalam arti praktis, pendidikan merupakan proses penyampaian kebudayaan atau proses pembudayaan yang bertujuan menjadikan anak memiliki keterampilan, pengetahuan, sikap-sikap, nilai-nilai, serta pola-pola perilaku tertentu. Mengacu pada pemahaman arti luas dan arti praktis, pendidikan itu bertujuan untuk mentransformasikan budaya, baik 
Implementasi Bimbingan Mengulang Kelas...

pendidikan di rumah tangga (keluarga), di masyarakat, maupun di sekolah, yang menunjukkan apa yang baik di masyarakat (Sagala, 2006: 227).

Undang-undang Nomor 20 Tahun 2003 tentang Sistem Pendidikan Nasional menyebutkan bahwa Pendidikan adalah usaha sadar dan terencana untuk mewujudkan suasana belajar dan proses pembelajaran agar peserta didik secara aktif mengembangkan potensi dirinya untuk memiliki kekuatan spiritual keagamaan, pengendalian diri, kepribadian, kecerdasan, akhlak mulia, serta ketrampilan yang diperlukan dirinya, masyarakat bangsa dan negara (pasal 1, butir 1). Mengenai tujuannya, dalam Undang Undang Sistem Pendidikan Nasional (UU No. 20 tahun 2003) berbunyi: "Pendidikan Nasional berfungsi mengembangkan kemampuan dan membentuk watak serta peradaban bangsa yang bermartabat dalam rangka mencerdaskan kehidupan bangsa, bertujuan untuk berkembangnya potensi peserta didik agar menjadi manusia yang beriman dan bertakwa kepada Tuhan Yang Maha Esa, berakhlak mulia, sehat, berilmu, cakap, kreatif, mandiri, dan menjadi warga negara yang demokratis serta bertanggung jawab.” Di pasal yang lain dinyatakan tujuan pendidikan nasional adalah mengembangkan potensi peserta didik untuk memiliki kecerdasan, kepribadian, dan akhlak mulia.

Dalam proses pendidikan, belajar menjadi salah satu kunci keberhasilan. Dimana belajar adalah upaya perubahan tingkah laku dengan serangkaian kegiatan seperti membaca, mendengar, mengamati, meniru, dan lain sebagainya. Seseorang itu belajar karena berinteraksi dengan lingkungannya dalam rangka mengubah tingkah laku (Sadirman, 2001: 53). Djumhur \& M. Surya mendefinisikan bimbingan belajar adalah bantuan yang diberikan kepada individu dalam memecahkan berbagai masalah kesulitan belajar, baik di sekolah maupun di luar sekolah agar individu dapat menyesuaikan diri dalam situasi belajar dengan baik (Djumhur \& Surya, 1978: 36).

Proses belajar akan semakin berhasil tercapai dengan adanya bimbingan. Yusuf \& Nurihsan dalam Hasan Bastomi (2019) Bimbingan bertujuan untuk membantu peserta didik agar dapat mencapai tujuan-tujuan perkembangannya 
yang meliputi aspek pribadi-sosial belajar (akademik) dan karir. Bimbingan menjadi penting adanya, untuk menjaga ritme dan semangat dalam proses belajar. Bimbingan dalam arti sempit berarti petunjuk, penjelasan dan sebagainya, yakni suatu tuntunan, pimpinan. Bimbing dapat pula diartikan pimpin, asuh atau tuntun. Dengan demikian secara bahasa, bimbingan merupakan suatu tuntunan yang bersifat membantu. Menurut Rochman Natawidjaja dalam bukunya Bimbingan Pendidikan dalam Sekolah Pembangunan sebagaimana yang dikutip oleh Juhana Wijaya merumuskan:

Bimbingan adalah suatu proses pemberian bantuan kepada individu yang dilakukan secara terus-menerus (continue) supaya individu tersebut dapat memahami dirinya, sehingga ia sanggup mengarahkan diri dan dapat bertindak wajar, sesuai dengan tuntutan dan keadaan lingkungan sekolah, keluarga, dan masyarakat. Dengan demikian dia dapat mengecap kebahagiaan hidupnya serta dapat memberikan sumbangan yang berarti kepada kehidupan masyarakat umumnya (Wijaya, 1988: 90). Sedangkan tujuan bimbingan belajar sebagai berikut: membantu siswa dalam menemukan cara-cara belajar yang efektif dan efisien, membantu siswa dalam merencanakan jadwal pelajaran secara efektif, menunjukkan cara-cara mempelajari suatu materi pelajaran, menunjukkan caracara membaca buku yang baik, membantu siswa dalam mengatasi masalah kesulitan belajar yang sedang dialami, menunjukkan cara pemanfaatan perpustakaan secara tepat, menunjukkan cara mempersiapkan diri dalam menghadapi ujian atau ulangan (Bastomi, 2020)

Dalam dunia pendidikan, ada satu hal menarik yang terjadi di Madrasah Qudsiyyah Kudus. Adanya fakta yang telah lama terjadi adanya proses bimbingan dalam mengulang kelas bagi siswa baru yang masuk di madrasah tersebut. Artinya, selama bertahun-tahun saat siswa masuk ke Madrasah Qudsiyyah Kudus, khususnya saat mau masuk ke jenjang Madrasah Tsanawiyah, mereka harus mengulang kelas dahulu di kelas MI. Kendati mereka telah lulus SD atau MI di sekolah sebelumnya, saat mereka masuk di MTs Qudsiyyah, harus rela mengulang kelas dan kembali mengulang di kelas VI MI. Artinya, mereka mengulang kembali 
Implementasi Bimbingan Mengulang Kelas...

kelas yang telah dilewati. Begitu pula saat akan masuk di tingkat Aliyah, tidak semua calon peserta didik yang mendaftar akan langsung diterima di kelas $\mathrm{X}$ Aliyah. Kebanyakan mereka akan mengulang kembali di kelas IX MTs Qudsiyyah. Fakta ini telah berjalan puluhan tahun dan hingga kini terus berjalan proses mengulang kelas tersebut.

Atas fakta ini, kaitannya dengan proses bimbingan dan pendidikan dan pembelajaran, bagaimana model bimbingan belajar mengulang kelas yang diterapkan, sehingga siswa tersebut secara sukarela mau dan betah mengulang kembali kelas yang pernah dilalui sebelumnya.

\section{B. Metode}

Dalam Penelitian ini mengunakan Metode Riset Lapangan (field research) dengan teknik analisis deskriptif kualitatif. Data penelitian yang terkumpul kemudian dianalisis dengan menggunakan pendekatan deduktif dan pendekatan induktif. Metode deduktif yaitu metode pembahasan dengan menggunakan pola pikir yang berangkat dari pengetahuan yang sifatnya umum, kepada penilain yang bersifat khusus. Sedangkan metode induktif yaitu suatu pengambilan keputusan dengan menggunakan pola pikir yang berangkat dari fakta-fakta yang sifatnya khusus kemudian digeneralisasikan kepada hal-hal yang bersifat umum mengenai implementasi bimbingan belajar mengulang kelas dalam menumbuhkan kemampuan akademik siswa baru di Madrasah Qudsiyyah Kudus.

\section{Pembahasan}

\section{Pengertian Bimbingan}

Menurut Shertzer dan Stone mendefinisikan bimbingan sebagaimana yang di kutip oleh Zulkifli Yusuf yaitu bahwasanya: Bimbingan sebagai satu proses menolong individu untuk memahami dirinya dan alam sekelilingnya. Proses ini menunjukkan satu usaha yang berterusan dan melibatkan banyak suatu langkah. Menolong disini bermaksud sebagai membantu. Individu di sini dimaksudkan kepada penuntut-penuntut sekolah atau siswa. Bimbingan juga merupakan satu 
proses pendidikan yang berterusan, tersusun dan sistematik serta dapat membantu individu melalui daya usahanya sendiri untuk mengembangkan kemampuanya, memperolehi kesejahteraan dalam hidupnya (Yusuf, 1998: 17).

Dari dua pengertian dari ahli tersebut, secara mudah dapat difahami bahwa bimbingan adalah bantuan yang diberikan kepada seseorang agar memperkembangkan potensi-potensi yang dimiliki, mengenali dirinya sendiri, mengatasi persoalan-persoalan sehingga dapat menentukan sendiri jalan hidupnya secara bertanggung jawab tanpa bergantung pada orang lain. Di sisi lain, karena pada dasarnya pendidikan adalah usaha sadar untuk mempersiapkan peserta didik melalui kegiatan pengajaran, bimbingan, dan atau latihan bagi perannya di masa yang akan datang. Maka dalam hal ini salah satu unsur pokok dalam kegiatan pendidikan, adalah bimbingan.

Bimbingan merupakan jenis kegiatan pendidikan yang terutama tertuju pada pertumbuhan kepada kepribadian manusia Indonesia yang bertakwa kepada Tuhan Yang Mahaesa, memelihara budi pekerti kemanusiaan, dan memegang teguh cita-cita moral rakyat yang luhur (Mudyahardjo, 2008: 57). Bimbingan merupakan unsur pokok dalam proses kegiatan pendidikan, yang merupakan serangkaian kegiatan atau langkah-langkah yang digunakan untuk mengubah kondisi awal peserta didik sebagai masukan, menjadi kondisi-kondisi ideal sebagai hasilnya. Proses-proses tersebut berlangsung dalam bentuk-bentuk kegiatan pendidikan yang berupa bimbingan.

Bimbingan sebagai pendidikan dan pengembangan yang menekankan proses belajar yang sistematik. Bimbingan sebagai pendidikan dan pengembangan yang menekankan pada proses belajar. Pengertian ini menekankan bimbingan sebagai bentuk pendidikan dan pengembangan diri, tujuan yang diinginkan diperoleh melalui proses belajar. Bimbingan merupakan sebuah layanan yang bersifat universal, yang tidak hanya di sekolah dan keluarga, tetapi di mana pun ada orang yang memerlukan bantuan dan di mana pun ada orang yang membantu. Dalam pelaksanaan bimbingan, tidak semua tugas dalam bimbingan harus dilaksanakan oleh para ahli di bidangnya masing-masing. Dalam hal tertentu 
Implementasi Bimbingan Mengulang Kelas...

kadang-kadang peranan guru maupun orang tua lebih menonjol dibandingkan dengan para ahli. Dimana guru atau orang tua sangat dekat dengan anak. Tetapi dari kesemuanya itu tergantung dari orang yang memerlukan bantuan.

Bimbingan merupakan suatu tuntunan. Bimbingan dapat diberikan kepada seorang individu atau sekumpulan individu. Bimbingan dapat diberikan baik untuk menghindari kesulitan-kesulitan maupun untuk mengatasi persoalan-persoalan yang dihadapi oleh individu di dalam kehidupanya. Hal ini berarti bahwa bimbingan dapat diberikan baik untuk mencegah agar kesulitan itu tidak atau jangan timbul, tetapi juga dapat diberikan untuk mengatasi kesulitan-kesulitan yang telah menimpa individu (Walgito, 2005: 4-5).

\section{Mengenal Program Mengulang Kelas di Madrasah Qudsiyyah}

Madrasah Qudsiyyah merupakan salah satu madrasah tua di Kudus. Madrasah yang berdiri sejak tahun 1919 dan lebih dari satu abad berdiri ini terdiri atas tingkatan formal MI, MTs, dan MA. Sementara untuk pendidikan non-formal membuka pondok pesantren dengan nama Ma'had Qudsiyyah. Madrasah yang didirkan oleh KHR Asnawi merupakan madrasah dengan pendidikan salaf yang menjadi ciri khas. Madrasah ini memiliki siswa dengan jenis kelamin laki-laki saja, tanpa ada campiran jenis kelamin perempuan. Hanya saja, seriring perkmebangan zaman, sejak tahun 2017, telah membuka kelas putri dan menerima ssiwa perempuan, hanya saja, tetap dipisah jauh antara siswa laki-laki dan siswa perempuan, sehingga tidak terjadi percampuran antara laki-laki dan perempuan dalam satu lokasi ataupun dalam satu kelas.

Madrasah Qudsiyyah, mempunyai sejarah yang cukup panjang. Madrasah Qudsiyyah tidak serta merta hadir dan menjadi besar, melainkan mengalami proses jatuh bangun yang cukup melelahkan. Madrasah Qudsiyyah telah berdiri tegak mengembangkan sayap-sayap pendidikan agama yang anti penjajah. Tercatat sejak 1917 M, kegiatan belajar mengajar telah dimulai, walaupun saat itu belum memiliki nama dan tempat belajar yang pasti. Dua tahun kemudian, tepatnya pada tahun 1919 M, yang bertepatan dengan tahun $1337 \mathrm{H}$, Madrasah Qudsiyyah resmi didirikan oleh KHR. Asnawi yang merupakan keturunan dari 
Sunan Kudus yang ke XIV dan keturunan kelima dari KH. A Mutamakin. Gedung Madrasah Qudsiyyah yang didirikan KHR. Asnawi saat itu berada di Kompleks Masjid al-Aqsha, tepatnya di depan gapura masuk Menara Kudus. Nama Qudsiyyah diambil dari kata Quds yang berarti suci dan sekaligus nama kota tempat kelahiran madrasah tersebut. Nama tersebut digunakan dengan maksud agar apa yang diajarkan serta diamalkan dalam madrasah menjadi benar-benar suci dan murni tidak dicampur-adukkan dengan yang kurang baik.

Dalam perjalanan panjang tentang sejarah madrasah, kondisi madrasah pada masa penjajahan Belanda diurus oleh Departemen voor Inlandsche Zaken, sebuah departemen pengajaran agama di lembaga pendidikan Islam (pesantren dan madrasah). Namun, Madrasah Qudsiyyah tetap bertahan dan tidak terpengaruh dengan lembaga pemerintah Belanda tersebut. Justru KHR. Asnawi sering melakukan perlawanan terhadap kebijakan pemerintahan Belanda. Hal ini terjadi lantaran pada praktiknya fungsi lembaga Belanda tersebut tidak menangani masalah pendidikan Islam dalam arti memfasilitasi, melainkan lebih merupakan sarana untuk mengontrol dan mengawasi lembaga-lembaga pendidikan yang ada. Oleh karenanya, pesan-pesan perjuangan melawan kolonialisme pada setiap kali beliau mengajar di madrasah senantiasa disampaikan kepada santri-santrinya.

Hingga tahun 1929 M, Madrasah Qudsiyyah dipimpin langsung oleh K.H.R. Asnawi sebagai kepala sekolah dan didampingi oleh KH. Shafwan Duri. Pada tahun 1929 M-1935 M Madrasah Qudsiyyah dipimpin oleh K. Tamyiz sebagai kepala sekolah. K.H.R. Asnawi sendiri, memimpin pondok pesantren Raudlatuth Thalibin yang didirikan pada tahun 1927 M di Bendan, Kerjasan Kudus. Pada tahun 1935 M, K. R. Sujono memimpin Qudsiyyah sampai dengan tahun 1939 M. Setelah K.R. Sujono wafat, Madrasah Qudsiyyah kemudian dipimpin oleh K.H. Abu Amar mulai tahun 1939 M sampai tahun 1943 M.

Buntut dari pemerintahan Dai Nippon Jepang yang menguasai Indonesia pada tahun $1943 \mathrm{M}$, ternyata berpengaruh terhadap pendidikan di Madrasah Qudsiyyah Kudus. Madrasah mengalami kemunduran drastis, bahkan hingga dilakukan penutupan. Awalnya ketika Jepang berkuasa, pemerintah Dai Nippon 
Implementasi Bimbingan Mengulang Kelas...

rupanya mencurigai kepada umat Islam. Tidak hanya sekadar curiga, bahkan pemerintah dengan tegas melarang mengajarkan semua pelajaran agama di madrasah-madrasah dengan tulisan arab. Jadi, saat itu semua pelajaran agama harus ditulis dengan huruf latin. Kebijakan tersebut membuat Madrasah Qudsiyyah menjadi salah satu korban. Pasalnya, berbagai pelajaran agama yang dahulunya menggunakan Bahasa Arab serta tulisan arab, kini dalam pengajarannya harus dijalankan dengan menggunakan tulisan latin.

Hal tersebut menyebabkan ketidaknyamanan di Madrasah Qudsiyyah. Alasannya, akan sangat berbeda tulisan dengan menggunakan tulisan arab diganti dengan tulisan latin. Selain itu, dalam pelaksanaannya madrasah-madrasah yang ada juga sering didatangi serdadu Dai Nippon. Sehingga berakibat jalannya pendidikan di madrasah-madrasah sangat terganggu. Hal ini kemudian membuat Madrasah Qudsiyyah merasa sangat terganggu. Dengan pertimbangan yang masakmasak oleh para Guru Madrasah Qudsiyyah, akhirnya keputusan pahit pun diambil, dan untuk sementara waktu Madrasah Qudsiyyah ditutup. Salah satu penyebab dari penutupan Madrasah Qudsiyyah Kudus adalah kekejaman tentara jepang yang terus mencurigai serta tidak diperkenankannya mengajar dengan menggunakan Bahasa Arab.

Namun, pendidikan yang dilakukan madrasah tidak berhenti begitu saja. Pendidikan di madrasah dialihkan dengan pengajian al-Qur'an pada setiap ba'dal maghrib yang diatur dengan kelas-kelas. Namun hal ini tidak bertahan lama, dan pada akhirnya berhenti juga. Praktis dalam masa ini pendidikan di madrasah lumpuh total. Masa penjajahan Jepang pun segera berakhir. Proklamasi kemerdekaan Republik Indonesia telah didengungkan ke dunia pada 17 Agustus tahun 1945. Namun, di awal kemerdekaan tersebut Madrasah Qudsiyyyah belum juga bangkit dari tidur panjangnya. Dan ternyata, cukup lama juga Madrasah Qudsiyyah tertidur dan kosong dari segala aktifitas. Barulah sekitar tahun 1950 M, Madrasah Qudsiyyah kembali menemukan ruhnya untuk bangkit kembali.

Perkembangan pendidikan di Madrasah Qudsiyyah semakin hari semakin meningkat hingga pada tanggal 25 Mei 1952 terwujudlah tingkat lanjutan pertama 
yang dinamakan Sekolah Menengah Pertama Islam Qudsiyyah (SMPIQ) dan mendapat perhatian penuh dari masyarakat. Semakin hari, sambutan dari masyarakat Kudus begitu besar terhadap pendidikan di Madrasah Qudsiyyah ini. Sehingga jumlah murid dari hari ke hari terus bertambah dan menyebabkan tingkat lanjutan dibagi menjadi dua, yaitu SMPI Qudsiyyah dan Pendidikan Guru Agama (PGA) Qudsiyyah. Pada tahun 1957, PGA Qudsiyyah dihapuskan dan SMPI Qudsiyyah dirubah namanya menjadi Madrasah Tsanawiyyah Qudsiyyah. Pada tahun 1970-an, Madrasah Qudsiyyah juga pernah membuka Madrasah Diniyyah sore hari. Keberadaan diniyyah ini berlangsung selama lima tahunan. Pada akhir tahun 1973 M, Madrasah Qudsiyyah mendirikan jenjang Aliyah untuk menampng alumni Tsanawiyahnya. Sejak itu, Madrasah Qudsiyyah semakin berkembang hingga sekarang (Profil Madrasah Qudsiyyah 2009: 5-15).

Dalam sistem pendidikan di Qudsiyyah, mengulang kelas bukanlah siswa yang gagal naik kelas, alias tinggal di kelas. Mengulang kelas merupakan istilah yang penulis gunakan untuk siswa baru yang masuk di madrasah Qudsiyyah yang ditempatkan di kelas yang pernah dijalani sebelumnya di sekolah lain. Hal ini misalnya siswa yang sudah pernah lulus MI atau SD, kemudian mendaftar di madrasah Qudsiyyah, tetapi kemudian ditempatkan di kelas V MI atau kelas VI MI Qudsiyyah. Inilah yang oleh penulis dikategorikan sebagai proses mengulang kelas. Proses kegiatan belajar mengajar (KBM) mengulang kelas telah ada dan tetap dilakukan oleh madrasah Qudsiyyah sejak dulu kala. Dari keterangan para sesepuh Madrasah Qudsiyyah. Proses KBM mengulang kelas telah ada pada dekade awal berdirinya madrasah Qudsiyyah. Hingga kini, proses KBM mengulang kelas masih terus dipertahankan sampai saat ini dan akan terus dipertahankan di masa depan.

Secara umum, proses KBM mengulang kelas dapat dilaksanakan karena Madrasah Qudsiyyah menganut sistem satu kesatuan antarunit Pendidikan. Antara MI, MTs dan MA Qudsiyyah merupakan satu kesatuan unit dalam hal manajemen dan dalam hal kurikulum. Artinya, kendati secara formal dan secara kelembagaan negara, antara ibtidaiyyah, tsanawiyyah dan aliyah merupakan jenjang yang berbeda, tetapi di madrasah Qudsiyyah, tiga jenjang tersebut adalah satu kesatuan 
Implementasi Bimbingan Mengulang Kelas...

dan saling mendukung satu sama lain. Dilihat dari sisi kurikulum, adalah keelanjutan dari apa yang telah dipelajari oleh unit yang ada di bawahnya. Misalnya, dari penggunaan kitab pada mata pelajaran Nahwu Shorof atau ilmu tentang tata cara Bahasa Arab, jenjang yang digunakan adalah melanjutkan dari dasar. Di MI pada mapel Nahwu Shorof mulai dikenalkan pada kelas 3 MI, kemudian kelas IV sudah menggunakan kitab pegangan Jurumiyyah, dilanjutkan kelas V juga menggunakan Jurumiyyah dan kelas VI menggunakan kitab Imrithi. Sedang kelas Tsanawiyah menggunakan kitab pegangan yang di atas Imrithi, yakni menggunakan kitab Alfiyyah ibn Malik selama tiga tahun, sementara di kelas Aliyah, selama tiga tahun menggunakan kitab syarah dari Alfiyyah ibn Malik yakni kitab Ibnu Aqil. Begitu pula pada mata pelajaran shorof, mulai kelas tiga MI sudah dikenalkan dengan materi shorof, kemudian kelas IV MI menggunakan kitab Amtsilatus Tashrifiyyah, kelas V melanjutkan Amstilatus Tashrifiyyah dan kelas VI 'unwanun Dhorof. Pada jenjang MTs shorof yang digunakan adalah mengambil bait dari kitab Alfiyyah ibnu Malik di bagian bait-bait akhir.

Selain mapel tata Bahasa yang saling bersinambung, mata pelajaran lain dalam hal ini salafiyah juga semua berkesinambungan. Dari mulai dasar sampai atas, dari mulai MI sampai Aliyah. Materi dasar membaca dan menulis dalam huruf arab sudah dikhatamkan dari kelas shifir (Pra MI/ setara TK) sampai kelas III MI. Materi ini merupakan bagian paling dasar yang harus dikuasai oleh siswa Qudsiyyah. Mulai dari membaca dan menulis bahasa arab, menulis pegon, hingga menulis indah bahasa Arab (kaligrafi). Kosa kata dan kalimat-kalimat pendek dalam bahasa arab juga mulai dihafalkan sejak kelas II ibtidaiyyah. Sehingga diharapkan, mulai kelas IV MI dan seterusnya, siswa tidak lagi perlu berkutat pada kesulitan menulis dan membaca Bahasa arab maupun tulisan pegon. Artinya mulai tingkat dasar di MI, penguatan pada sisi penguasaan bahasa arab dan segala aspeknya dititikbebaratkan untuk dikuasai setiap murid. Pada akhirnya, pada jenjang berikutnya, yakni pada jenjang tsanawiyah, akan dikenalkan kepada kitabkitab kuning, yakni buah tangan para ulama-ulama terdahulu yang disebut dengan kitab kuning dimana kitab tersebut tercetak tanpa menggunakan harakat. Para 
siswa tingkat tsanawiyah dipersiapkan dapat membaca, memahami serta dapat mengartikan teks-teks dalam bahasa arab yang tertulis pada kitab kuning. Pada tingkat selanjutnya, yakni mulai kelas IX Tsanawiyah, siswa akan dikenalkan dengan syair-syair dalam bahasa arab serta segala keunikan serta sastra bahasa arab. Selain itu di masa ini siswa akan dikenalkan juga dengan rahasia-rahasia Bahasa Arab dari sisi makna, yakni melalui mata pelajaran balaghah. Di fase ini siswa akan dikenalkan kenapa harus menggunakan kata-kata tertentu dalam bahasa arab yang itu memiliki banyak makna dan sebagainya. Rahasia-rahasia ini akan diungkap untuk menunjukkan ketinggian bahasa arab yang akan dikupas tuntas para siswa.

Tujuan dari pengenalan bahasa arab sejak dini tak lain adalah untuk mempersiapkan siswa memahami berbagai literature-literatur klasik karya ulamaulama terdahulu yang menyimpan banyak mutiara di dalamnya, yang sampai sekarang ini masih sedikit sekali yang dialihbahasakan ke dalam bahasa negeri ini. Dengan bekal ilmu tata bahasa arab sejak dari mulai MI, MTs dan MA diharapkan output dari lulusan Aliyah Qudsiyyah mampu memahami kitab-kitab kuning yang telah dipelajari selama ini, Lebih-lebih mampu memahami kitab-kitab besar yang belum diajarkan. Dengan bekal ilmu-ilmu bahasa arab, ilmu tata bahasa Nahwu Shorof, para siswa Qudsiyyah dipersiapkan dapat dengan mudah memahami bahasa arab, baik saat ditulis lengkap dengan harakat maupun saat ditulis gundulan, tanpa harakat sebagaimana dalam kitab kuning.

Dari sisi pelajaran lain juga seperti itu, rentetan materinya bertahap demi setahap. Fiqih misalkan, dari kelas III MI sudah dimulai dengan fiqih jawan, dilanjutkan kelas IV hingga kelas VI dengan Addurusul fiqhiyyah, kemudian di tingkat MTs, karena sudah dibekali dengan dasar Nahwu Shorof di tingkat MTs, maka materi fiqih di level MTs adalah Taqrib dan kemudian di tingkat Aliyah adalah Tuhfatuth Thullab. Dari rentetan struktur kurikulum, secara sederhana dapat disimpulkan bahwa masing-masing jenjang di tiap tingkatan memiliki tugas dan tanggung jawab sendiri dalam menfokuskan mata pelajaran yang menjadi dasar serta menjadi tangga untuk naik ke jenjang berikutnya. Oleh karenanya 
Implementasi Bimbingan Mengulang Kelas...

secara umum, dari MI Qudsiyyah, MTs Qudsiyyah dan MA Qudsiyyah merupakan satu kesatuan yang tidak bisa dipisahkan. Oleh karenanya, wajar jika ada siswa dari luar yang masuk ke Qudsiyyah harus melewati fase-fase atau materi yang telah diajarkan di tingkat dasar tersebut. Terlalu beresiko, bila tanpa dasar penguasaan bahasa arab, ujug-ujug langsung diterima di kelas VII MTs Qudsiyyah, meskipun ia sudah lulus SD atau MI. Sebab, siswa tanpa dasar bahasa arab, akan sangat kesulitan untuk mengikuti pelajaran yang ada di MTs.

Logika sederhana ini bisa dimaklumi. Para calon siswa di kelas VII MTs atau kelas X MA harus sudah menguasai materi dasar yang ada di tingkat MI maupun materi yang ada di tingkat MTs bagi yang akan masuk di kelas Aliyah. Oleh karenanya, di madrasah Qudsiyyah menerapkan sistem perektutan dengan adanya tes masuk sekolah. Karena antar unit menjadi satu-kesatuan, maka panitia penerimaan santri baru dari jenjang tersebut adalah satu kepanitiaan. Panitia pendaftaran MI, MTs dan Ma dibentuk dari pengurus dalam satu kepanitian untuk penerimaan santri pada tiga jenjang MI, MTs dan MA.

\section{Model Bimbingan Mengulang Kelas}

a. Penempatan Kelas Sesuai kemampuan

Sebagaimana diurai di atas, program mengulang kelas, telah ada di awal-awal madrasah ini berdiri. Pada dekade 70-an sampai tahun 80-an, tes masuk di Qudsiyyah sudah diterapkan. Bahkan, tes mausk dilakukan mulai dasar kelas shifir. Artinya, pada saat itu, saat calon santri sudah lulus SD/MI, maka akan menjalani tes kembali dari pelajaran kelas satu MI Qudsiyyah. Pada tahun-tahun itu, sudah biasa, calon murid dari luar Qudsiyyah yang sudah lulus SD/MI di luar Qudsiyyah saat mendaftar di Qudsiyyah akan kembali mengulang kelas satu atau kelas dua MI Qudsiyyah. Itu banyak dialami santri pada saat tahun tahun seperti itu.

Pada dekade 90-an tes masuk tetap diadakan tetapi tidak seketat sebelumnya yakni dites mulai materi kelas satu. Pada tahun 90-an ini tes masuk dimulai dengan materi baca tulis pegon serta Nahwu Shorof. Pada tahun-tahun ini pada santri baru yang lulusan SD/MI di luar Qudsiyyah 
banyak yang masuk di kelas IV MI, hanya mereka yang pintar yang bisa masuk di kelas V atau kelas VI Qudsiyyah.

Pada dekade tahun 2000-an tes masuk mulai sedikit diperlonggar, dan hanya difokuskan pada nahwu shorof dasar. Pada tahun ini tes masuk umumnya akan masuk kelas V dan kelas VI MI.

Pada tahun 2007 pertama kalinya ada santri yang bisa langsung masuk di kelas VII MTs, dan itupun mereka yang memiliki kemampuan tinggi dengan nilai tes yang memuaskan. Rata-rata mereka banyak yang masuk kelas VI Qudsiyyah. Begitu yang sudah lulus MTs/SMP di luar Qudsiyyah maka akan dimulai kelas satu MTs lagi, bahkan pada tahun 90-an saat sudah lulus SMP karena merasa tidak memiliki bekal keilmuan agama, rela ditempatkan di kelas V atau kelas VI MI Qudsiyyah.

Saat ini, bagi yang lulus SD/MI di luar Qudsiyyah akan dilakukan tes masuk dengan tes adalah materi dasar Nahwu shorof. Bila hasilnya cukup baik maka akan bisa masuk kelas VII MTs, bila tidak maka di kelas VI MI Qudsiyyah. Sekarang ini, untuk masuk langsung kelas VII MTs akan dibatasi cukup satu kelas saja, maksimal dua kelas, sekitar 40 santri yang bisa masuk Qudsiyyah, selebihnya masuk di kelas VI Qudsiyyah.

Dari data yang diperoleh dari panitia penerimaan santri baru dalam kurun waktu tiga tahun terakhir, tercatat paling banyak siswa di luar Qudsiyyah masuk di kelas VI dan kelas IX, hanya beberapa yang masuk di Aliyah dan yang bisa langsung masuk di kelas VII MTs Qudsiyyah. Lebih jelasnya, bisa dilihat pada data penempatan kelas santri baru di bawah ini.

Data Penempatan Kelas Santri Baru Madrasah Qudsiyyah

\begin{tabular}{clccc}
\hline No & Kelas & $\begin{array}{c}\mathbf{2 0 1 7 -} \\
\mathbf{2 0 1 8}\end{array}$ & $\begin{array}{c}\mathbf{2 0 1 8}- \\
\mathbf{2 0 1 9}\end{array}$ & $\begin{array}{c}\mathbf{2 0 1 9 -} \\
\mathbf{2 0 2 0}\end{array}$ \\
\hline 1 & Shifir & 38 & 51 & 46 \\
\hline 2 & 1 Ibtidaiyyah & 56 & 56 & 89 \\
\hline 3 & 2 Ibtidaiyyah & 0 & 6 & 4 \\
\hline 4 & 3 Ibtidaiyyah & 4 & 5 & 5 \\
\hline 5 & 4 Ibtidaiyyah & 6 & 4 & 6 \\
\hline
\end{tabular}


Implementasi Bimbingan Mengulang Kelas...

\begin{tabular}{clccc}
\hline 6 & 5 Ibtidaiyyah & 3 & 2 & 2 \\
\hline 7 & 6 Ibtidaiyyah & 156 & 183 & 262 \\
\hline 8 & 7 Tsanawiyyah & 63 & 60 & 53 \\
\hline 9 & 8 Tsanawiyyah & 1 & 4 & 1 \\
\hline 10 & 9 Tsanawiyyah & 21 & 40 & 52 \\
\hline 11 & 10 Aliyah & 17 & 22 & 9 \\
\hline & $\begin{array}{l}\text { Belum ada } \\
\text { kelasnya (tidak } \\
12\end{array}$ & & & \\
\hline$\quad$ & jadi masuk) & 26 & 30 & 33 \\
\hline & Jumlah total & $\mathbf{3 9 1}$ & $\mathbf{4 6 3}$ & $\mathbf{5 6 2}$ \\
\hline
\end{tabular}

Fakta di atas menunjukkan penyesuaian diri akan kemampuan siswa dikelompokkan di kelas tertentu. Mereka yang mendapatkan nilai tinggi dalam tes masuk, akan ditempatkan di kelompok yang tinggi, yakni bisa langsung masuk di kelas VII MTs atau kelas X MA. Sebaliknya, mereka yang mendapatkan nilai yang rendah dalam tes masuk akan ditempatkan di kelompok kelas mengulang, yakni kelompok kelas VI MI dan kelas IX MTs.

Penempatan kelas ini akan memudahkan dalam bimbingan siswa menuju proses pembelajaran selanajutnya. Karena pada dasarnya bimbingan pada kelas mengulang ini adalah seyogyanya mempersiapkan bekal dasar para santri untuk dapat mengikuti jenjang pelajaran di tingkat atasnya.

b. Bimbingan Kelompok Mengulang Kelas

Secara umum kebutuhan layanan bimbingan dan konseling timbul karena adanya problem-problem yang dihadapi. Siswa sebagai manusia dan makhluk sosial tentunya membutuhkan suatu bimbingan untuk menyelesaikan problem yang dialami. Pada umumnya problem akan muncul ketika siswa mulai memasuki madrasah baru. Dan hal itu akan terus berlanjut selama siswa menempuh pendidikannya di madrasah jika tidak segera diberi penanganan dalam rangka mengatasi problem-problem tersebut.

Salah satu hal yang di madrasah Qudsiyyah adalah dengan melakukan bimbingan dengan pendekatan bimbingan kelompok pada kelas mengulang. 
Secara teori, bimbingan kelompok dapat berupa penyampaian informasi ataupun aktivitas kelompok membahas masalah-masalah pendidikan, pekerjaan, pribadi dan sosial (Sukardi \& Kusmawati, 2008: 23).

Bimbingan kelompok akan lebih efektif karena selain peran individu juga akan memunculkan terjadinya pertukaran fikiran, pengalman serta rencana dan penyelesaian masalah. Bimbingan kelompok memungkinkan sejumlah peserta didik secara bersama-sama melalui dinamika kelompok memperoleh berbagai bahan dari narasumber tertentu terutama dari guru dan konselor unhtuk bersama-sama membhasan masalah yang sedang dihadapi. Tujuannya adalah untuk menunjang perkmebangan pribadi dan perkmebangan sosial masing-masiang anggota kelompok serta meningkatkan mutu kerja sama kelompok guna mencapai aneka tujuan bermakna para partisipan (Winkel \& Sri Hastuti, 2010: 547).

Dalam konteks bimbingan kelompok pada program mengulang kelas di mdrasah Qudsiyyah, semua guru berperan aktif untuk membimbing peserta didik dalam memahami peran serta meningkatkan kemampuan santri dalam memahami dasar-dasar Bahasa arab serta ilmu yang menyertainya. Tujuannya adalah untuk memberi bekal keilmuan yang spesfisik untuk mampu mengikuti materi di kelas di atasnya.

Oleh karenanya, dalam bimbingan kelompok ini tentu saja menyusun kurikulum yang berbeda dengan kelompok lain. Ada spesifikasi kurikulum terntu yang dijalankan dibandingkan dengan kelas yang sama, tetapi bukan dariprogram mengulang kelas. Kurikulum pada mengulang kelas focus pada pembentukan keilmuan dasar emngenai Bahasa arab, nahwu shorof dasar dan ilmu alat lainnya. Sementara di program kelas lain, kurikulum yang dijalankan juga kurikulum yang utuh, yakni kurikulum Kemenag serta muatan lokal mta pelajatan salafiyyah yang menjadi ciri khas madrasah Qudsiyyah.

\section{Kelebihan dan Kekurangan Bimbingan Mengulang Kelas}

a. Kelebihan Bimbingan Mengulang Kelas 
Implementasi Bimbingan Mengulang Kelas...

1) Membangun Fondasi Dasar Memahami Kitab Kuning

Pada dasarnya, bimbingan mengulang kelas yang diterapkan di madrasah Qudsiyyah adalah untuk membangun kemampuan siswa dalam menghadapi problem dan materi yang ada di kelas selanjutnya. Dalam hal ini adalah fokus pada materi tentang pelajaran salafiyyah, mata pelajaran muatan lokal yang berbasis pada teks-teks kitab kuning. Istilah kitab kuning merupakan istilah yang digunakan masyarakat untuk menyebut kitab-kitab berbahasa Arab. Sejak masa silam, kitabkitab berbahasa Arab ini biasa digunakan banyak pesantren sebagai materi pelajaran para santri.

Dengan kata lain, mengulang kelas di madrasah Qudsiyyah adalah untuk menyiapkan diri terhadap para santri untuk dapat menguasai materi dasar dalam rangka menguasai materi kitab kuning di kelas selanjutnya. Materi-materi dasar Bahasa arab inilah yang fokus digenjot untuk diberikan kepada santri. Sebagaimana diakui kepala MI Qudsiyyah, M. Afthoni, kelas VI santri baru yang berasal dari luar Qudsiyyah tidak perlu lagi pusing mikir ujian nasional. Tetapi hanya focus pada materi materi persiapan dasar-dasar dalam keilmuan Bahasa arab dalam rangka menyiapkan diri memahami Bahasa arab dalam kitab-kitab kuning sebagai materi wajib yang ada di kelas kelas selanjutnya di madrasah Qudsiyyah

Materi-materi dasar dalam memahami Bahasa arab adalah materi nahwu, shorof, lughoat dan tentu saja membaca dan menulis pegon. Terkadang diakui ada siswa yang sama sekali belum bisa menulis dan membaca huruf arab maupun huruf pegon. Terhadap siswa inilah pentingnya bimbingan mengulang kelas yang ada di madrasah Qudsiyyah akan diberikan. Umumnya, memang banyak calon santri yang belum pernah memperoleh pelajaran nahwu shorof dan bhasa arab. Oleh karenanya pelakjaran dasar ini penting sebagai keilmuwan dasar bagi santri untuk memperolah materi-materi berikutnya. Bila 
dipaksanakan langsung bisa masuk kelas VII MTs, maka akan cukup kesulitan untuk mengejar pelajaran salafiyyah yang menjadi pelajaran unggulan di madrasah Qudsiyyah.

2) Tidak Disibukkan Ujian Nasional

Umumnya target saat kelas enam MI atau kelas IX MTs adalah tentang kelulusan dan melalui ujian dengan mulus, sehingga akan mudah naik tingkatan. Tetapi bagi program mengulangkelas yang ada di kelas VI dan kelas IX madrasah Qudsiyyah, bukan itu yang menjadi target. Target yang harus dicapai oleh siswa adalah menguasasi materi dasar Bahasa arab untuk melanggeng ke jenjang berikutnya. Target kelas IX Mts Qudsiyyah adalah sudah menguasai pembacaan kitab kuning, minimal fathul qarib.

Target ini menjadi penting untuk dikuasai karena di tingkatan berikutnya, beban materi dasar ini tak lagi dipelajari. Ara santri akan dijejali dengan materi-materi baru yang umumnya merupakan tingkat di atasnya, sehingga target dasar harus lah terpenuhi. Sehingga tidak kepontal pada tingkatan berikutnya. Pada mengulang kelas ini, para siswa tidak lagi disibukkan dengan persiapan materi mapel ujian nasional, karena sesungguhnya ia telah lulus ujian nasional. Ia hanya ditugaskan untuk fokus pada materi pelajaran salafiyyah yang menjadi ciri khas pelajaran yang bakal dipeganginya.

b. Kelebihan Bimbingan Mengulang Kelas

1) Menghabiskan Waktu dan Usia

Di satu sisi, kehadiran model mengulang kelas memang mampu membuat siswa focus pada bidang keunggulan yang ada di sekolah. Dalam hal ini, keberadaan sistem mengulang kelas di Madrasah Qudsiyyah adalah untuk menyiapkan siswa untuk fokus pada materi salafiyah, yakni untuk memahami materi-materi karya ulama klasik yang tertulis dalam kitab kuning. 
Implementasi Bimbingan Mengulang Kelas...

Di sisi lain, model mengulang kelas tentu menghabiskan banyak waktu dan menghabiskan usia. Apalagi bila model mengulang kelas tidak cukup hanya satu tahun, maka siswa membutuhkan banyak waktu bertahun-tahun untuk mempersipakan diri dan waktu sekolah siswa menjadi lebih panjang dan lebih lama dibanding teman-teman lain yang tidak mengulang kelas. Kekurangan lain dari sistem ini adalah dari sisi usia. Bila model bimbingan kelas berlangsung lama, bertahun-tahun, maka akan terbentur dengan peraturan Kemendibkud dan Peraturan Kemenag soal batasan usia saat mendaftar di tingkat SD/MI atau SMP/MTs. Dalam peraturan bersama antara Menteri Pendidikan dan Menteri Agama tahun 2011, disebutkan, usia calaon peserta didik tingkat SD/Mi adalah usia minimal 6 tahun dan maksimal 12 tahun. Sedang usia calon peserta didik saat mendaftar pada tingkat MTs/SMP adalah maksimal berusia 18 tahun.

2) Keengganan Calon Siswa Mengulang kelas

Umumnya, sekolah adalah sesuai step dan naik tingkat. Bila sudah lulus SD atau MI, maka step selanjutnya adalah masuk di tingkatan SMP atau MTs. Tetapi di Madrasah Qudsiyyah berbeda, calon santri meskipun telah lulus SD/MI belum tentu akan langsung masuk di kelas 7 MTs Qudsiyyah. Mereka akan menjalani tes seleksi dulu. Bisa langsung masuk di MTs tetapi paling banyak akan mengulang kemabli di kelas 6 MI. Hal ini tentu saja membuat calon siswa dan calon orang tua siswa yang akan masuk di Qudsiyyah menjadi enggan, dan pada akhirnya tidak jadi masuk di Qudsiyyah.

\section{Simpulan}

Implementasi Mengulang Kelas di Madrasah Qudsiyyah bukanlah gagal naik kelas, tetapi program yang dijalani oleh peserta didik baru yang ditempatkan di kelas tertentu. Kelas tertentu ini sama tingkatannya dengan kelas sebelumnya di madrasah atau sekolah terdahulu. Bedanya di program mengulang ini tidak lagi dipusingkan dengan ujian nasional dan hanya fokus pada kurikulum salafiyyah. 
Bimbingan yang dilaksanakan di madrasah Qudsiyyah pada program Mengulang kelas adalah dengan mengelompokkan sesuai kemampuannya. Peserta didik yang mendapatkan nilai tinggi dalam tes masuk dapat langsung masuk pada jalur non mengulang kelas. Sebaliknya, peserta didik yang mendapatkan nilai rendah harus mengulang kelas dan dikelompokkan pada kelas tertentu.

Model bimbingan mengulang kelas di Madrasah Qudsiyyah dilakukan secara kelompok dengan membentuk kurikulum tersendiri yang mana dapat focus pada kurikulum salafiyah dsar sebagai bekal materi salafiyah di tingkat lanjutan. Bimbingan materi salafiyah dasar ini dilakukan oleh semua guru, tidak hanya dibebankan pada guru BK, tetapi semua guru bertanggungjawab pada proses bimbingan meningkatkan kemampuan dasar peserta didik baru ini.

Penelitian ini bukanlah akhir. Masih banyak penelitian lanjutan yang dapat dilakukan. Mislanya, penelitian focus pada bagaimana efektivitas bimbingan yang dilakukan pada program mengulang kelas ini. Selain itu, bagaimana perbandingan dengan peserta didik yang tanpa melalui program mengulang kelas ini. Artinya bagaimana tingkat keberhasilan bimbingan mengulang kelas dengan program non mengulang kelas di Madrasah Qudsiyyah ini dapat diteliti lebih lanjut. Selain itu, faktor usia dan faktor lamanya melakukan proses pendidikan di madrasah Qudsiyyah, karena harus ada program mengulang kelas ini juga bisa menjadi focus penelitian lanjutan, khususnya pendapat peserta didik dan orang tua peserta didik. 


\section{DAFTAR PUSTAKA}

Bastomi, H. (2019). Konseling Cyber: Sebuah Model Konseling Pada Konteks Masyarakat Berbasis Online. Konseling Edukasi: Journal of Guidance and Counselling, 3, No. 1.

Bastomi, H. (2020). Pemetaan Masalah Belajar Siswa SMK Negeri 3 Yogyakarta Dan Penyelesaiannya (Tinjauan Srata Kelas). KONSELING EDUKASI: Journal Of Guidance And Counseling, 4 No. 1.

Djumhur, L., \& Surya, M. (1978). Bimbingan Dan Penyuluhan Di Sekolah: Guidance and Conseling. Bandung: Ilmu.

Mudyahardjo, R. (2008). Filsafat Ilmu Pendidikan. Bandung: Remaja Rosadakarya.

Sadirman. (2001). Interaksi dan Motivasi Belajar Mengajar. Jakarta: RajaGrafindo Persada.

Sagala, E. J. (2006). Manajemen Berbasis Sekolah dan Masyarakat, Strategi Memenangkan Persaingan Mutu. Jakarta: Rakasta Samasta.

Sukardi, D. K., \& Kusmawati, D. N. (2008). Proses Bimbingan dan Konseling di Sekolah. Jakarta: Rineka Cipta.

Sulhan, N. (2010). Pendidikan Berbasis Karakter. Surabaya: Jepe Press Media Utama.

Tim Penyusun. (2009). Profil Madrasah Qudsiyyah. Kudus: Madrasah Qudsiyyah

Undang-undang Nomor 20 Tahun 2003 tentang Sistem Pendidikan Nasional Pasal 1

Walgito, B. (2005). Bimbingan dan Konseling (Studi dan Karir). Yogyakarta: Andi Offset.

Wijaya, J. (1988). Psikologi Bimbingan. Bandung: Eresco.

Winkel \& Sri Hastuti. (2010). Bimbingan dan Konseling di Institut Pendidikan. Yogyakarta: Media Abadi.

Yusuf, Z. (1998). Panduan Khidmat Bimbingan. Selangor: Percetakan Dewan Bantara dan Pustaka. 